\title{
PENINGKATAN PENGELUARAN ASI DENGAN KOMBINASI PIJAT OKSITOSIN DAN TEKNIK MARMET \\ PADA IBU POST PARTUM (LITERATUR REVIEW)
}

\author{
Lieni Lestari ${ }^{1)}$ Melyana Nurul $\mathrm{W}^{2)}$ Admini $^{3)}$ \\ E-mail address: lenykayla023@gmail.com
}

\begin{abstract}
Breastmilk is very useful for babies at the beginning of their lives because it contains a lot of antibodies for the baby's immunity that can prevent diseases that cause the death of infants and toddlers. One of the factors that a mother cannot give immediate is breast milk expenditure that is not smooth in the first days after giving birth. The delayed release of breast milk can be caused by a lack of stimulation of the hormone oxytocin and prolactin which are very instrumental in smoothing out breastfeeding expenditure. This non effortless release of breast milk can be stimulated by a combination of Oxytocin Massage and Marmet Technique.

The aim of the study was to identify the literature review relating to oxytocin massage and marmet technique. Methods: This study uses literature (literature review) about the benefits of applying oxytocin massage and marmet techniques. The source for conducting this review is in the form of 8 research articles from 2013 to 2017. The research design was descriptive by analyzing two international journals and six national journals relating to oxytocin massage and marmet technique. Results: Oxytocin massage and marmet techniques can be categorized as safe and effective interventions to increase for the spending of breastmilk in postpartum mothers who experience problems with breast milk production. Conclusion: Oxytocin massage and marmet techniques can increase for the spending of breastmilk.
\end{abstract}

Keywords: oxytocin massage; marmet techniques; spending of breastfmilk.

${ }^{1)}$ Borneo Health Sciences College Cendekia Medika Pangkalan Bun

2) Poltekkes Kemenkes Semarang

${ }^{3)}$ Puskesmas I Wangon, Banyumas Regency

\section{Pendahuluan}

Angka Kematian Bayi di Indonesia berdasarkan Hasil Survei Demografi dan Kesehatan Indonesia (SDKI) tahun 2012 masih cukup tinggi yaitu sebesar 32 kematian per 1.000 kelahiran hidup (SDKI, 2012) target Sustainable Development Goals 3 (SDG's) menurunkan angka kematian neonatal hingga 12 per 1.000 kelahiran hidup dan angka kematian balita 25/1.000 kelahiran hidup.
Bayi baru lahir perlu mendapat perawatan yang optimal sejak dini termasuk pemberian makanan yang ideal. Tidak ada satupun makananan yang ideal untuk bayi baru lahir selain ASI. World Health Organitation (WHO) dan United Nation International Children's Emergency Fund (UNICEF) menganjurkan pemberian ASI saja sampai bayi berusia 6 bulan, tanapa pemberian 
cairan tanpa makanan selain ASI (IDAI, 2013).

UNICEF menyebutkan bahwa kematian sekitar 30 ribu anak di Indonesia setiap tahunnya dapat dicegah melalui pemberian ASI secara eksklusif selama 6 bulan sejak kelahiran bayi (Hikmawati, 2008). Suraji (2003) juga menjelaskan bahwa ASI memberikan peranan penting dalam menjaga kesehatan dan mempertahankan kelangsungan hidup bayi.

Dalam menanggulangi hal ini, Pemerintah telah menetapkan Peraturan Pemerintah No 33 Tahun 2012 Tentang Pemberian Asi Eksklusif, Peraturan Pemerintah tersebut menyatakan bahwa setiap bayi harus mendapatkan asi ekskusif yaitu ASI yang dberikan kepada bayi sejak dilahirkan selama 6 (enam) bulan, tanpa menambahkan dan/atau mengganti dengan makanan atau minuman lain (Kemenkes, 2012).

Hasil riset di Eropa membuktikan pemberian ASI mendukung anak meraih pendidikan lebih tinggi. Hasil senada diperoleh riset yang dilakukan di Denmark pada 3.203 anak. Anak yang menyusu ASI kurang dari satu bulan memiliki tingkat IQ lebih rendah dibanding yang memperoleh ASI hingga 7-9 bulan. ASI juga meningkatkan daya tahan tubuh anak. Berdasarkan riset yang dimuat dalam buletin Lancet pada tahun 2013 diungkapkan, pemberian ASI bisa menekan kematian balita hingga 13 persen (Widiani, 2013).

Hasil penelitian oleh Siregar (2004) yang menunjukkan bahwa pemberian ASI ekslusif dipengaruhi oleh berbagai faktor antara lain ASI tidak segera keluar setelah melahirkan/produksi ASI kurang, kesulitan bagi bayi dalam menghisap, keadaan puting susu ibu yang tidak menunjang, ibu bekerja dan pengaruh promosi pengganti ASI.

Colin dan Scott (2002) dalam penelitiannya yang dilakukan di Australia menjelaskan bahwa 29\% ibu post partum berhenti menyusui karena produksi ASI berkurang. Sedangkan penelitian yang dilakukan oleh Ahluwia, Morrow, dan Hasia (2005) ditemukan bahwa ibu-ibu berhenti menyusui bayinya pada bulan pertama post partum disebabkan karena puting lecet, kesulitan dalam melakukan perlekatan yang benar serta persepsi mereka tentang ketidak cukupan produksi ASI ibu sehingga tidak dapat memuaskan bayi. Kenyataan di lapangan menunjukkan produksi dan ejeksi ASI yang sedikit pada hari-hari pertama setelah melahirkan menjadi kendala dalam memberikan ASI secara dini. Menurut Cox (2006) ibu yang tidak dapat menyusui pada harihari pertama disebabkan oleh kecemasan dan ketakutan ibu akan kurangnya produksi ASI serta kurangnya pengetahuan ibu tentang proses menyusui (Mardiyaningsih, 2010). Kecemasan dan ketakutan yang dialami ibu tersebut akan menyebabkan penurunan hormon oksitosin, sehingga ASI tidak dapat keluar segera setelah melahirkan, sehingga akhirnya ibu memutuskan untuk memberikan susu formula pada bayinya

Usaha untuk merangsang hormon prolaktin dan oskitosin pada ibu setelah melahirkan selain dengan memeras ASI, dapat dilakukan juga dengan melakukan perawatan atau pemijatan payudara, membersihkan puting, sering-sering menyusui bayi meskipun ASI belum keluar, menyusui dini dan 
teratur serta pijat oksitosin (Biancuzzo, 2003; Indriyani, 2006).

Pijat oksitosin dilakukan untuk merangsang refleks oksitosin atau refleks let down. Pijat oksitosin ini dilakukan dengan cara memijat pada daerah punggung sepanjang kedua sisi tulang belakang sehingga diharapkan dengan dilakukan pemijatan ini, ibu akan merasa rileks dan kelelahan setelah melahirkan akan hilang. Jika ibu rileks dan tidak kelelahan setelah melahirkan dapat membantu merangsang pengeluaran hormon oksitosin. (Depkes RI, 2007).

Pijat oksitosin merupakan salah satu solusi untuk mengatasi ketidak lancaran produksi ASI. Pijat oksitosin adalah pemijatan pada sepanjang tulang belakang (vertebrae) dan merupakan usaha untuk merangsang hormon oksitosin setelah melahirkan (Biancuzzo, 2003; Indiyani, 2006; Yohmi \& Roesli, 2009 dalam Mardiyaningsih, 2010).

Selain pijat oksitosin cara memperlancar pengeluaran ASI salah satunya dengan teknik marmet yaitu teknik memerah ASI yang dianjurkan dengan mempergunakan tangan dan jari karena praktis, efektif dan efisien dibandingkan dengan menggunakan pompa. Caranya memerah ASI menggunakan cara Cloe Marmet yang disebut dengan Teknik Marmet yang merupakan perpaduan antara teknik memerah dan memijat. Memerah dengan menggunakan tangan dan jari mempunyai keuntungan selain tekanan negatif dapat diatur, lebih praktis dan ekonomis karena cukup mencuci bersih tangan dan jari sebelum memeras ASI (Roesli, 2010).

Untuk itu petugas kesehatan mempunyai peranan penting untuk mengajarkan kepada keluarga agar dapat membantu ibu melalukan pijat oksitosin dan teknik marmet karena teknik pijatan ini cukup mudah dilakukan dan tidak menggunakan alat tertentu. Selain itu memperbanyak asupan nutrisi yang seimbang dan konsumsi sayuran hijau. Serta dukungan suami dan keluarga juga sangat dibutuhkan untuk meningkatkan produksi dan pengeluaran Air Susu Ibu (ASI).

Oleh karenanya penulis tertarik untuk melakukan miniriset dengan tujuan untuk mengetahui efektivitas kombinasi pijat oksitosin dan teknik marmet terhadap pengeluaran ASI pada ibu post partum di puskesmas 1 Wangon.

\section{Metode Penelitian}

Jenis studi ini adalah meta data analisis dengan menggunakan tinjauan literatur (literature review) yang mencoba menggali tentang manfaat penerapan kombinasi pijat oksitosin dan teknik marmet terhadap pengeluaran ASI pada ibu post partum. Sumber dalam melakukan tinjauan ini meliputi studi pencarian pada Science Direct dan Google Scholar dalam bentuk jurnal penelitian sejumlah 17 jurnal yang diteliti pada tahun 2013 hingga 2017 yang membahas tentang manfaat penerapan pijat oksitosin dan teknik marmet terhadap produksi ASI pada ibu post partum. Dari 17 jurnal terbagi menjadi 8 jurnal sebagai telaah utama yang merupakan 2 jurnal internasional terakreditasi dan 6 jurnal nasional yang terakreditasi, dan 9 jurnal sebagai kepustakaan. Keyword yang digunakan adalah "Oxytocin Massage/Pijat Oksitosin", Marmet Techniques /Teknik Marmet", Spending of Breastmilk/Pengeluaran $A S I^{\prime}$. Sampelnya berupa 2 jurnal 
internasional yang terakreditasi dan 6 jurnal nasional yang terakreditasi. Artikel yang diperoleh ditelaah, disusun secara sistematis, dan dibandingkan satu sama lain dan dibahas dengan literatur terkait.

\section{Hasil dan Pembahasan}

Pencarian jurnal yang dilakukan pada data base dengan kata kunci : pijat oksitosin, teknik marmet, pengeluaran ASI. Hasil literatur review didapatkan sampel berupa 2 jurnal internasional yang terakreditasi dan 6 jurnal nasional yang terakreditasi yang meneliti tentang manfaat penerapan pijat oksitosin dan teknik marmet terhadap pengeluaran ASI ibu post partum.

Menurut penelitian yang dieliti oleh (Dr. Umesh Patel, DKK., 2013), berjudul "Effect of back Massage on Lactation among Postnatal Mothers"dengan jumlah responden sebanyak 220 ibu post partum yang dibagi menjadi dua kelompok yaitu kelompok eksperimental dan kelompok kontrol. Tujuan penelitian ini adalah untuk menilai efektivitas pijat punggung terhadap laktasi ibu pasca melahirkan. Didapatkan hasi yaitu pada kelompok studi terdapat Kenaikan berat badan bayi yang signifikan setelah dilakukan penerapan pijat punggung ,jumlah rata-rata BAK dan $\mathrm{BAB}$ perhari lebih tinggi, durasi tidur bayi juga meningkat lebih lama setelah menyusui. Hal ini lebih baik dibandingkan kelompok kontrol. Penelitian ini menunjukkan bahwa pijat punggung efektif dalam meningkatkan laktasi, hal ini dapat direkomendasikan untuk semua ibu menyusui khususnya mereka yang menghadapi masalah dengan inisiasi dan upaya menyusui.
Menurut penelitian dari (Fionie Tri Wulandari Fidyah Aminin Utami Dewi, 2014), yang berjudul "Pengaruh pijat oksitosin terhadap pengeluaran kolostrum pada ibu post partum di RSUD Propinsi Kepulauan Riau". Tujuan dari penelitian ini untuk mengetahui Pengaruh pijat oksitosin terhadap pengeluaran kolostrum pada ibu post partum di Rumah Sakit Umum Daerah Provinsi Kepulauan Riau. Jenis penelitian yang digunakan adalah quasy experiment dengan rancangan yang digunakan post test only design with control group. Teknik pengambilan sampel dengan non probability sampling dengan 15 responden kelompok perlakuan dan 15 responden kelompok kontrol. Hasil penelitian ini, menunjukkan pada kelompok perlakuan rerata waktu pengeluaran Kolostrum 5.21 jam. Sedangkan hasil yang diperoleh pada kelompok yang tidak dilakukan pijat oksitosin (kontrol) rerata waktu pengeluaran Kolostrum 8.16 jam. Hasil tersebut menunjukkan terdapat perbedaan waktu pengeluaran kolostrum antara ibu post partum yang dipijat oksitoksin (perlakuan) dengan ibu yang tidak dilakukan pijat oksitoksin (kontrol). Penelitian ini menunjukkan bahwa ada pengaruh pijat oksitosin terhadap pengeluaran kolostrum.

Menurut penelitian dari (Rani Rahayu, Annisa Andriyani Sekolah Tinggi Ilmu Kesehatan 'Aisyiyah Surakarta, 2014), yang berjudul "Metode memperbanyak ASI pada ibu post sectio caesarea dengan teknik marmet dan breast care di RSUD Karanganyar" . Tujuan penelitian ini untuk mengetahui perbedaan teknik marmet dan breast care terhadap produksi asi pada ibu sectio caesarea. 
Metode penelitian yang digunakan yaitu Quasi eksperiment pretestpostest with control group design, pengambilan sampel menggunakan teknik purposive sampling jumlah sampel 16 pada kelompok perlakuan dan 16 pada kelompok kontrol instrument penelitian menggunakan lembar observasi. Hasil Uji paired ttest kelompok intervensi menunjukkan ada perbedaan produksi Asi sebelum dan sesudah diberikan tekik marmet ( $p$ value) $0.000<0,05$, uji paired t-test kelompok kontrol menunjukkan ada perbedaan sebelum dan sesudah diberikan breast care ( $p$ value) 0.000 $<0,05$ uji independent t-test menunjukkan tidak ada perbedaan produksi Asi sebelum dan sesudan diberikan eknik marmet dan breast care antara kelompok perlakuan dan kelompok kontrol ( $p$ value) 0.274 $>0,05$.

Menurut penelitian yag dilakukan oleh (Anita Widiastuti, Siti Arifah, Wiwin Renny Rachmawati, 2014), yang berjudul "Pengaruh teknik marmet terhadap kelancaran ASI dan kenaikan berat badan bayi". Tujuan dari penelitian ini untuk mengetahui perbedaan pengaruh teknik marmet dengan masase payudara pada ibu nifas tiga hari postpartum terhadap kelancaran ASI dan kenaikan berat badan bayi. Metode penelitian ini menggunakan desain pre-experimental bentuk perbandingan kelompok statistik. Sampel yang digunakan adalah 40 responden postpartum dengan dibagi menjadi 2 kelompok (20 kelompok pertama diberi perlakuan teknik marmet dan 20 kelompok kedua diberi perlakuan masase payudara). Berdasarkan hasil uji beda pengaruh teknik marmet dengan masase payudara pada ibu nifas tiga hari postpartum terhadap kelancaran ASI menggunakan uji Mann Whitney $U$, diketahui teknik marmet memiliki ratarata peringkat 23,70 , sedangkan masase payudara memiliki peringkat 17,30 . Pada hasil uji statistik dengan CI 95\% diperoleh nilai $\mathrm{p}=0,047$. Berdasarkan hasil ini, secara statistik terdapat perbedaan teknik marmet dengan masase payudara dalam memengaruhi kelancaran ASI. Pemberian perlakuan teknik marmet menyebabkan pengeluaran ASI lebih lancar. Secara statistik, terdapat perbedaan pada kelancaran ASI antara responden yang diberikan perlakuan teknik marmet dengan responden yang diberikan masase payudara.

Menurut penelitian yang dilakukan oleh (Ira Titisari, Rahajeng Siti Nur Rahmawati, 2016), berjudul "Perbandingan efektifitas kombinasi teknik marmet dan pijat oksitosin dengan breast care terhadap produksi Asi pada ibu post partum”. Tujuan dari penelitian ini untuk membandingkan efektivitas teknik pemijatan Marmet dan oksitosin dengan perawatan payudara terhadap produksi ASI ibu pada post partum. Metode penelitian yang digunakan quasi eksperimental desain Desain penelitian yang digunakan Post Only Design, Teknik pengambilan sampel yaitu consecutive sampling dengan sampel sebanyak 30 responden. Pengumpulan data dilakukan dengan membagi menjadi 2 kelompok: kelompok yang diberikan Marmet dan teknik memijat oksitosin dan kelompok yang diberikan perawatan payudara. Berdasarkan hasil analisa dengan menggunakan Wilcoxon Mann Whitney $U$ Test didapatkan hasil $\mathrm{p}$-value $=0,870>$ Alpa 0,05 yang artinya tidak ada perbedaan berat badan dan Frekuensi 
BAK setelah dilakukan tehnik marmet dan pijat oksitosin dan breast care. Dari hasil analisa tersebut menunjukkan bahwa tidak ada perbedaan antara kombinasi teknik marmet dan pijat oksitosin dan breast care terhadap produksi ASI. Ketiga teknik tersebut sama-sama efektif dalam meningkatkan produksi ASI pada ibu post partum.

Menurut penelitian dari (Khusnul Hamidah, Yuli Isnaeni, 2016), yang berjudul "Pengaruh teknik marmet terhadap produksi Asi pada ibu post partum di RS PKU Muhammadiyah Gamping”. Tujuan penelitian ini adalah untuk menganalisis pengaruh teknik marmet terhadap produksi asi pada ibu post partum. Metode penelitian yaitu analitik experimental dengan pendekatan static group comparison/posttestonly control group design. Sampel berjumlah 40 responden diambil melalui teknik quota sampling. Sumber data menggunakan data primer yang dikumpulkan melalui lembar observasi. Uji statistik menggunakan uji Chi Square. Hasil penelitian menunjukkan pada ibu postpartum kelompok eksperimen dengan Produksi ASI dengan kategori banyak sebesar $75.0 \%$ (15 responden), sedangkan pada kelompok kontrol responden dengan Produksi ASI dengan kategori banyak sebesar $40.0 \%$ (8 responden). Artinya ada pengaruh teknik marmet terhadap produksi ASI pada ibu post partum di Rumah Sakit PKU Muhammadiyah Gamping.

Menurut penelitian yang dilakukan oleh (Awlia Mar'atus Sholihah , Kusumastuti, 2017), yang berjudul "Penerapan teknik marmet dan pijat oksitosin dengan minyak lavender untuk meningkatkan produksi Asiibu post partum". Tujuan Melakukan asuhan kebidanan pada ibu nifas dengan melakukan penerapan teknik marmet dan pijat oksitosin dengan minyak lavender untuk meningkatkan produksi ASI. Metode penelitian yaitu teknik pengumpulan data yang digunakan adalah deskriptif analitik dengan pendekatan Studi Kasus (Case Study). Teknik yang digunakan dalam menentukan partisipan yaitu purposive sampling berdasarkan kriteria dengan jumlah partisipan 5 orang. Sumber data menggunakan data primer yang dikumpulkan melalui lembar observasi. Hasil penelitian penerapan teknik marmet dan pijat oksitosin dengan minyak lavender sebelum dilakukan penerapan menunjukkan bahwa BB lahir bayi 4 partisipan $(80 \%)>3000$ gram, BAK bayi dan frekuensi menyusu semua partisipan (100\%) sebanyak 1 kali, lama tenang / tidur semua partisipan (100\%) tidak dapat tidur. Setelah dilakukan penerapan menunjukkan bahwa dari 5 partisipan pada hari ke-14 terdapat 4 partisipan $(80 \%)$ BB bayi $>3000$ gram, seluruh partisipan $(100 \%)$ BAK $>6$ kali sehari dan menyusu $>8$ kali dalam sehari, kemudian 3 partisipan $(60 \%)$ tidur selama 2 jam.

Menurut penelitian yang dilakukan oleh (Kadek Yuli Hesti, Noor Pramono, Sri Wahyuni, Melyana Nurul Widyawati, Bedjo Santoso , 2016), yang berjudul "EFFECT OF COMBINATION OF BREAST CARE AND OXYTOCIN MASSAGE ON BREAST MILK SECRETION IN POSTPARTUM MOTHERS".

Tujuan penelitian ini Untuk menguji pengaruh kombinasi perawatan payudara dan pijat oksitosin pada sekresi air susu ibu pada postpartum ibu-ibu. Metode penelitian 
eksperimental quasy dengan percobaan kontrol non-acak dengan kelompok kontrol pretest-posttest. Ada 44 ibu postpartum yang diambil dalam penelitian ini menggunakan purposive sampling, yang 22 ditugaskan di kelompok eksperimen dan kontrol. Data dianalisis menggunakan dependent t-test dan Mann Whitney test. Hasil menunjukkan ada peningkatan yang signifikan dari sekresi air susu ibu dalam kelompok eksperimen dan kontrol dengan $\mathrm{p}$-value $0,000 \quad(<0,05)$. Pada kelompok eksperimen, terjadi peningkatan sekresi ASI dari 17,09 menjadi 220,91 cc, dan pada kontrol kelompok ada juga peningkatan dari 17,09 menjadi 72,00 cc. Perbedaan rata-rata sekresi air susu ibu antara pretest dan posttest dalam kelompok eksperimen adalah 203,82 dan pada kelompok kontrol adalah 54,90 dengan $\mathrm{p}$-value $0,000 \quad(<0,05)$. Ada peningkatan yang signifikan dari sekresi air susu ibu pada ibu post partum setelah diberikan kombinasi pijat oksitosin dan perawatan payudara dalam kelompok eksperimen dibandingkan dengan pendidikan dan konseling tentang perawatan payudara di kelompok kontrol. Dengan demikian, hasil ini dapat digunakan sebagai bukti untuk melakukan pijat oksitosin dan perawatan payudara untuk meningkatkan sekresi air susu ibu pada ibu postpartum.

Dari hasil literatur review terhadap 8 artikel, dapat dijelaskan bahwa pijat oksitosin dan teknik marmet dapat dikategorikan sebagai intervensi yang aman dan cukup efektif dalam peningkatan produksi ASI atau Pengeluaran ASI pada ibu post partum yang mengalami masalah dalam produksi ASI yang tidak mendapatkan terapi medis lain yang digabungkan dalam proses tindakan, dilaksanakan dalam kurun waktu 3-14 hari.

Hasil telaah beberapa artikel diatas penerapan pijat oksitosin dilakukan pada ibu post partum dengan waktu selama 3-14 hari dan pemijatan oksitosin dilaksanakan selama 3 menit dengan cara memijat sepanjang tulang belakang dari costa ke lima sampai keenam dengan kedua ibu jari dengan cara memutar. Hal ini dapat merangsang hormon oksitosin sehingga menyebabkan payudara memproduksi ASI.

Pada beberapa artikel yang lain menyebutkan bahwa teknik marmet juga efektif membantu produksi ASI yaitu dengan cara memerah ASI menggunakan Teknik Marmet yang merupakan perpaduan antara teknik memerah dan memijat. Pemijatan dengan menggunakan jari-jari tangan dan sedikit tepukan pada payudara akan merangsang hormon prolaktin. Memerah dengan menggunakan tangan dan jari-jari mempunyai keuntungan selain tekanan dapat diatur, cara ini lebih praktis dan ekonomis karena cukup dengan mencuci bersih tangan dan jari kita sebelum memeras ASI.

Pijat oksitosin juga merupakan stimulasi yang dapat diberikan untuk merangsang pengeluaran ASI. Pijatan ini memberikan rasa nyaman pada ibu setelah mengalami proses persalinan dapat dilakukan selama 2-3 menit secara rutin 2 kali dalam sehari (Depkes, 2007).

Pijat oksitosin yaitu suatu cara untuk membantu mempercepat pengeluaran ASI atau Kolostrum dengan rangsangan pijatan pada kedua sisi tulang belakang, mulai dari 
leher kearah tulang belikat dilanjutkan ke tulang costae di bawah kedua payudara ibu post partum (Perinasia, 2007).

Melalui pijatan atau rangsangan pada tulang belakang, neurotransmitter akan merangsang medulla oblongata langsung mengirim pesan ke hypothalamus di hypofise posterior untuk mengeluarkan oksitosin sehingga menyebabkan payudara mengeluarkan air susunya. Dengan pijatan didaerah tulang belakang ini juga akan merileksasi ketegangan dan menghilangkan stress, dengan begitu hormon oksitosin keluar dan akan membantu pengeluaran Air Susu Ibu (ASI), dibantu dengan isapan bayi pada puting susu saat setelah bayi lahir dengan keadaan bayi normal (Guyton,2007).

Teknik marmet merupakan kombinasi cara memerah ASI dan memijat payudara sehingga refleks ASI dapat optimal. Teknik memerah ASI dengan cara marmet bertujuan untuk mengosongkan ASI dari sinus laktiferus yang terletak di bawah areola sehingga dengan mengosongkan ASI pada sinus laktiferus akan merangsang pengeluaran prolaktin. Pengeluaran hormon prolaktin diharapkan akan merangsang mammary alveoli untuk memproduksi ASI. Semakin banyak ASI dikeluarkan atau dikosongkan dari payudara akan semakin baik produksi ASI di payudara( Widiastutik, 2015).

Dalam literatur review ini beberapa penelitian menjelaskan bahwa pijat oksitosin efektif dalam meningkatkan produksi ASI karena dengan Pijat oksitosin dapat merangsang pengeluaran hormone oksitosin yang bekerja memacu refleks pengeluaran ASI. Oksitosin itu sendiri diproduksi oleh kelenjar pituitary posterior, oksitosin yang masuk ke dalam aliran darah ibu dan merangsang sel otot di sekeliling alveoli berkontraksi . Dengan pijatan di daerah tulang belakang ini juga akan merelaksasikan ketegangan dan menghilangkan stress, dan dengan begitu hormon oksitosin keluar akan membantu pengeluaran air susu ibu, kolostrum yang menetes atau keluar merupakan tanda aktifnya reflex oksitosin.

Sedangkan beberapa literatur juga mengatakan bahwa teknik marmet juga sangat efektif untuk memperlancar produksi ASI, teknik memerah ASI dengan cara marmet akan mengosongkan ASI dari sinus laktiferus yang terletak di bawah areola sehingga dengan mengosongkan ASI pada sinus laktiferus akan merangsang pengeluaran prolaktin. Pengeluaran hormon prolaktin juga dapat merangsang mammary alveoli untuk memproduksi ASI, sehingga semakin banyak ASI dikeluarkan atau dikosongkan dari payudara akan semakin baik produksi ASI di payudara.

Pada artikel ini penelitian dilaksanakan pada Wilayah Kerja Puskesmas 1 Wangon Kabupaten Banyumas, yang dilakukan pada 2 responden yang memiliki keluhan ASI tidak lancar. Perlakuan diberikan pada ibu dengan cara kombinasi pijat oksitosin dan teknik marmet yang dilakukan selama 3 hari dengan waktu penerapan $1 \mathrm{x}$ dalam sehari dengan waktu 10-15 menit. Dari penerapan kombinasi pijat oksitosin dan teknik marmet akan merangsang 
pengeluaran hormone oksitosin yang bekerja memacu refleks pengeluaran ASI. Oksitosin diproduksi oleh kelenjar pituitary posterior, hormon oksitosin yang masuk ke dalam aliran darah ibu dan merangsang sel otot di sekeliling alveoli berkontraksi sehingga dengan pijatan di daerah tulang belakang akan memberikan rasa nyaman dan rileksasi, menghilangkan stress dan dengan begitu hormon oksitosin keluar dan akan membantu pengeluaran air susu ibu. Kolostrum yang menetes atau keluar merupakan tanda aktifnya reflex oksitosin. Pijatan di daerah payudara akan mengosongkan ASI dari sinus laktiferus yang terletak di bawah areola sehingga akan membantu peningkatan produksi ASI. Setelah dilakukan penerapan kombinasi pijat oksitosin didapatkan hasil bahwa produksi ASI mengalami peningkatan, ibu merasa lebih rileks dan bahagia, payudara ibu terlihat lunak dan kosong setelah menyusui, Frekuensi menyusu bayi lebih sering, tidur cukup yaitu 2-3 jam setelah menyusu dan BAK lebih dari 7x per hari. Pada artikel ini menunjukkan bahwa penerapan kombinasi pijat oksitosin dan teknik marmet efektif untuk meningkatkan pengeluaran ASI, aman dan memberikan efek relaksasi bagi ibu menyusi karena hormon prolaktin yang dilepaskan.

Literatur lain mengkombinasikan pijat oksitosin dengan perawatan payudara, dan teknik marmet dengan breast care. Hasil yang didapatkan sama-sama memiliki keunggulan masing-masing dan dapat meningkatkan dan memperlancar produksi ASI. Banyak teknik yang dapat digunakan untuk memperlancar ASI bila dilakukan dengan tepat dan benar akan mendapapatkan hasil yang baik, oleh karenanya perlu peningkatan edukasi bagi masyarakat khususnya ibu dan keluarga dalam hal pemberian ASI eksklusif, perawatan payudara, nutrisi seimbang, teknik menyusui yang benar, sehingga akan tercapai cakupan ASI yang baik.

\section{Simpulan}

Berdasarkan analisa yang dilakukan oleh penulis, disimpulkan bahwa penerapan pijat oksitosin dan teknik marmet efektif untuk meningkatkan produksi ASI pada ibu post partum yang tidak mendapatkan terapi lainnya selama penerapan berlangsung. Ada peningkatan pada pengeluaran ASI setelah dilakukan penerapan pijat terhadap pengeluaran air susu ibu pada ibu post partum ditandai dengan pengeluaran ASI yang cukup.

Saran yang dapat diberikan pada tenaga kesehatan dan masyarakat agar pijat oksitosin dan teknik marmet dapat dijadikan prosedur tetap sebagai pelayanan postpartum dan diberikan juga konseling tentang pijat oksitosin dan teknik marmet kepada ibu hamil dan ibu menyusui di Puskesmas I Wangon 


\section{Daftar Pustaka}

Hamidah K. PENGARUH TEKNIK MARMET TERHADAP PRODUKSI ASI PADA IBU POST PARTUM DI RUMAH SAKIT PKU MUHAMMADIYAH GAMPING: Universitas' Aisyiyah Yogyakarta; 2016.

Wijayanti L. Pengaruh Pijat Oksitosin Terhadap Produksi ASI Pada Ibu Post Partum di Puskesmas Mergangsan Yogyakarta Tahun 2014: $\quad$ STIKES'Aisyiyah Yogyakarta; 2014.

Ningrum AD, Titisari I, Kundarti FI, Setyarini AI. Pengaruh Pemberian Teknik Marmet Terhadap Produksi Asi Pada Ibu Post Partum Di Bpm Wilayah Kerja Puskesmas Sukorame Kota Kediri. Jurnal Ilmu Kesehatan. 2017;5(2):46-55.

Titisari I, Rahmawati RSN. PERBANDINGAN EFEKTIFITAS KOMBINASI TEKNIK MARMET DAN PIJAT OKSITOSIN DENGAN BREAST CARE TERHADAP PRODUKSI ASI PADA IBU POST PARTUM. Jurnal Ilmu Kesehatan. 2016;5(1):87-95.

Mardiyaningsih E, Sabri L. Efektifitas kombinasi teknik marmet dan pijat oksitosin terhadap produksi ASI ibu post seksio di Rumah Sakit Wilayah Jawa Tengah. Jurnal Keperawatan Soedirman. 2011;6(1):31-8.

Albertina M. Hubungan Pijat Oksitosin Dengan Kelancaran Produksi ASI pada Ibu Post Partum Seksio Sesarea hari ke 2-3. Husada Mahakam. 2017;3(9):452-8.

Ummah F. Pijat oksitosin untuk mempercepat pengeluaran ASI pada ibu pasca salin normal di Dusun Sono Desa Ketanen Kecamatan Panceng Gresik. Jurnal Surya. 2014;2.

Wulandari FT, Aminin F, Dewi U. PENGARUH PIJAT OKSITOSIN TERHADAP PENGELUARAN KOLOSTRUM PADA IBU POST PARTUM DI RUMAH SAKIT UMUM DAERAH PROVINSI KEPULAUAN RIAU. Jurnal Kesehatan. 2016;5(2).

Endah SN, Masdinarsah I. Pengaruh pijat oksitosin terhadap pengeluaran kolostrum pada ibu post partum di ruang kebidanan Rumah Sakit Muhammadiyah Bandung Tahun 2011. Jurnal kesehatan kartika. 2011. 